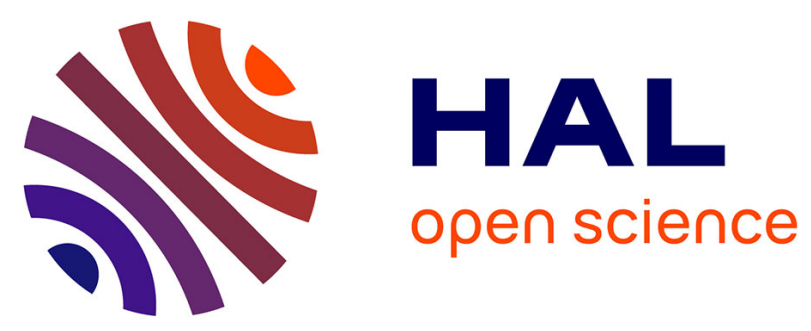

\title{
Structural reorganization of the India-Arabia strike-slip plate boundary (Owen Fracture Zone; NW Indian Ocean) 2.4 million years ago
}

Mathieu Rodriguez, Philippe Huchon, Nicolas Chamot-Rooke, Marc Fournier, Matthias Delescluse

\section{To cite this version:}

Mathieu Rodriguez, Philippe Huchon, Nicolas Chamot-Rooke, Marc Fournier, Matthias Delescluse. Structural reorganization of the India-Arabia strike-slip plate boundary (Owen Fracture Zone; NW Indian Ocean) 2.4 million years ago. Joao C. Duarte. Transform Plate Boundaries and Fracture Zones, Elsevier, pp.146-155, 2019, 10.1016/B978-0-12-812064-4.00007-4 . hal-02326725

\section{HAL Id: hal-02326725 \\ https://hal.science/hal-02326725}

Submitted on 22 Oct 2019

HAL is a multi-disciplinary open access archive for the deposit and dissemination of scientific research documents, whether they are published or not. The documents may come from teaching and research institutions in France or abroad, or from public or private research centers.
L'archive ouverte pluridisciplinaire HAL, est destinée au dépôt et à la diffusion de documents scientifiques de niveau recherche, publiés ou non, émanant des établissements d'enseignement et de recherche français ou étrangers, des laboratoires publics ou privés. 


\title{
CHAPTER 7
}

\section{Structural reorganization of the India-Arabia} strike-slip plate boundary (Owen Fracture

\section{Zone; NW Indian Ocean) 2.4 million years ago}

\author{
Mathieu Rodriguez ${ }^{1}$ \\ Philippe Huchon ${ }^{2}$ \\ Nicolas Chamot-Rooke ${ }^{1}$ \\ Marc Fournier $^{2}$ \\ Matthias Delescluse ${ }^{1}$ \\ ${ }^{1}$ Laboratoire de Géologie, Ecole normale supérieure, CNRS UMR8538, PSL research university, Paris, France \\ ${ }^{2}$ Sorbonne Universités, UPMC Université Paris 06, CNRS UMR 7193, ISTeP, Paris, France
}

\begin{abstract}
The Owen Fracture Zone (OFZ) is the present-day, 800-km-long dextral India Arabia plate boundary, with conspicuous pull-apart basins at stepover areas and at its terminations. We summarize geological evidence documenting the age of formation of the OFZ, based on detailed analysis of geophysical and drilling data in the vicinity of the main pull-apart basins. Although India-Arabia motion started in the Late Cretaceous, we show that the present-day OFZ is a young structure formed at $2.4 \mathrm{Ma}$. This last structural reorganization of the India-Arabia plate boundary is unrelated to any well-documented kinematic change, leaving questions over its driver.
\end{abstract}

Keywords: Fracture zone - pull apart- horsetail- Indian Ocean 


\section{1 - Introduction}

Strike-slip plate boundaries display a large variety of geological structures along their strike, especially in areas where the layout of the displacement zone is discontinuous or curved (Mann, 2007). These step-over areas favor the formation of releasing or restraining bends, according to the configuration of adjacent strike-slip fault segments and the local stress field (Sylvester, 1988). Detailed tectonic and stratigraphic investigations have revealed that strike-slip boundaries experience dramatic episodes of structural reorganization during their lifetime, marked by the formation of new structures and the abandonment of older ones (ten Brink and BenAvraham, 1989; Wakabayashi, 2007; Brothers et al., 2009; Schattner, 2010; ten Brink and Flores, 2012; Le Pichon et al., 2001, 2013). Models of structural evolution have proposed that continental strike-slip boundaries initiate as diffuse, en-_ echelon fault systems and become narrower with increasing maturity (Tchalenko, 1970; Wesnousky, 2005; Dooley and Schreurs, 2012; Le Pichon et al., 2016). This pattern of structural evolution is modulated by the layered rheology of the continental lithosphere (Le Pourhiet et al., 2014).

The structural evolution of oceanic strike-slip faults (with seismicity identified along their entire length) has been investigated only for a few cases, including the MacQuarie Fault (Australia-Pacific boundary; Massel et al., 2000; Meckel et al., 2005) or the Azores-Gibraltar transform fault (Nubia-Eurasia boundary; Zitellini et al., 2009; Rosas et al., 2014; Miranda et al., 2014). Here we focus on the oceanic India-Arabia strike-slip plate boundary, which initiated $\sim 90 \mathrm{Ma}$ when India separated from Madagascar (Bernard and Munschy, 2000) and started its motion toward Eurasia. The India-Arabia plate boundary experienced several episodes of migrations in response to India-Eurasia or Arabia-Eurasia collision (Rodriguez et al., 2014a,b, 2016). Multibeam mapping of the current India-Arabia plate boundary (Fig. 1), referred to as the Owen fracture zone (OFZ) in the Arabian Sea, revealed dextral morphological offsets of the Owen Ridge on the order of $10-12 \mathrm{~km}$ (Fournier et al., 2008a,b, 2011) - the Owen Ridge being a series of bathymetric highs uplifted 8.7 Ma ago (Rodriguez et al., 2014a, b, 2018). Considering steady the current right-lateral motion of $3 \pm 1 \mathrm{~mm} \mathrm{yr}^{-1}$ (DeMets et al., 2010), these offsets indicate a recent reorganization of the OFZ, younger than the Late Miocene.

Using multibeam and seismic data, tied to nearby ODP-DSDP sites, we performed detailed structural and stratigraphic studies to investigate the age of formation of each major structure (mainly pull-apart basins) observed along the OFZ in order to determine its age of formation. The results show that the present-day expression of the entire, 800-km-long OFZ formed at 2.4 Ma, from the Aden-Owen-Carlsberg triple junction to the Makran subduction zone (Fig. 1) and involved the opening of conspicuous pull-apart basins (from south to north: the Beautemps-Beaupré Basin, Fig. 2; the $20^{\circ} \mathrm{N}$ Basin, Fig. 3; the Dalrymple Trough, Fig. 4).

\section{2 - THE SEDIMENTARY RECORD OF STRIKE-SLIP TECTONICS ALONG THE OWEN FRACTURE ZONE}

\subsection{The Indus Turbiditic Channels}

The OFZ crosses the distal Indus turbidite fan, which is fed from the east by the Indus canyon cutting through the NW Indian margin (von Rad and Tahir, 1997; Rodriguez et al., 2011, 2013, 2014a, b; Bourget et al., 2013). Turbiditic channels are observed on both sides of the OFZ (Figs. 3 and 4). In terms of relative chronology, the turbiditic channels observed west of the OFZ (in the Owen Basin) predate its formation and indicate a period of limited tectonic activity, or a period when sedimentation rates were too high to record tectonics. East of the OFZ, the turbiditic channels trapped or deviated by strike-slip structures postdate the formation of the OFZ. Dating the different turbiditic systems provides good age brackets for the formation of the OFZ. The age of a turbiditic channel is estimated from the age of the first pelagic layer that covers it.

\subsection{Fault-Controlled Contourite Drifts}

Bottom currents influence the geometry of deep-sea sedimentary deposits and build conspicuous sedimentary formations referred to as contourite drifts (Rebesco et al., 2014). In the vicinity of the OFZ, several fault-controlled contourite drifts are observed within the pelagic blanket lying over the turbiditic channels (Figs. 3 and 4). The opening of pull-apart basins along the OFZ induced local perturbations of bottom current. The base of a fault-controlled drift indicates the minimum age of formation of the fault. 


\subsection{Angular Unconformities}

Vertical motion of the seafloor (uplift or subsidence) related to faults results in major angular unconformities within the Indus fan, sometimes outlined by conspicuous fanning configurations recording the growth of the structure. Within the fanning configurations, numerous unconformities reflect the control of sealevel variations at the 105 years time-scale over the Indus fan sedimentation (Bourget et al., 2013).

\section{3 - AGE OF STRUCTURES ALONG THE OWEN FRACTURE ZONE}

\subsection{The Beautemps-Beaupré Pull-Apart Basin}

The Beautemps-Beaupré Basin is a 120 -km-long, 50-km-wide rhomboidal pull-apart basin located at the southern termination of the OFZ (Fig. 2; Fournier et al., 2008a,b). The Beautemps-Beaupré Basin is almost entirely filled in by Indus turbidites. The basin is bounded to the south by the Beautemps-Beaupré Ridge (Rodriguez et al., 2018), which corresponds to a tilted section of Indus turbidites (Fig. 2). Numerous angular unconformities are identified at the edges of the basin (Fig. 2), most of them being related to interruptions of Indus sedimentation related to sea-level variations (Bourget et al., 2013). The onset of the uplift of the Beautemps-Beaupré Ridge is recorded by a conspicuous angular unconformity and the base of the fanning configuration of a sequence of Indus sediments (Fig. 2; Rodriguez et al., 2018). This unconformity can be tracked within the Beautemps-Beaupré Basin, where it coincides with the onset of lateral variations in thickness of turbidites, which marks the onset of seafloor subsidence there. Since its uplift above the level of turbidites deposition, the Beautemps-Beaupré Ridge is blanketed by pelagic sediments that can be correlated with pelagic sediments on top of the nearby Owen Ridge (Fig. 2), where ODP sites provide stratigraphic constraints (Discoaster pentaradius; Shipboard Scientific Party, 1989). This unconformity is dated at 2.4 Ma (Rodriguez et al., 2014b, 2018).

\subsection{The $20^{\circ} \mathrm{N}$ Pull-Apart Basin}

The $20^{\circ} \mathrm{N}$ Basin, named after its latitude, is an asymmetric, 90-km-long, 12-km-wide pullapart basin (Fig. 3; Fournier et al., 2011). The OFZ constitutes the western flank of the $20^{\circ} \mathrm{N}$ Basin, while imbricated systems of arcuate normal faults dissect its eastern flank (Fig. 3). The $20^{\circ} \mathrm{N}$ Basin is divided into three subbasins by the transverse faults (Fig. 3). Fossil turbidite channels are identified west of the basin, whereas the currently active channel is captured on the eastern side of the basin (Rodriguez et al., 2011; Bourget et al., 2013). The most recent fossil turbidite channel to the west is dated at 3.4 $\pm 1.2 \mathrm{Ma}$ (Rodriguez et al., 2013), which gives the maximal age of the opening of the basin (Fig. 3). A fault-controlled contourite drift, with a typical sigmoid geometry, is also identified on the top of the master fault (Fig. 3). The opening of the basin may have disturbed the course of the bottom current and triggered the building of the drift. The reflector marking the base of the drift can be correlated within the pelagic cover as far as the ODP sites located at the top of the Owen Ridge. The age of this reflector is $2.4 \mathrm{Ma}$ (Rodriguez et al., 2013, 2014b).

\subsection{The Dalrymple Trough}

The Dalrymple Trough marks the northern termination of the OFZ (Edwards et al., 2000; Ellouz Zimmermann et al., 2007). The southern segment of the Dalrymple Trough is a 150-km-long, 30-km-wide horsetail termination basin (Fig. 4), with numerous oblique splays connecting the OFZ (Fournier et al., 2011; Rodriguez et al., 2014b). The Dalrymple Trough is flanked to the east by the Murray Ridge. Indus turbidite channels dated at $3.7 \pm 1 \mathrm{Ma}$ to the west of the Dalrymple Trough predate its opening (Fig. 4). In contrast to the $20^{\circ} \mathrm{N}$ and Beautemps-Beaupré basins, the Dalrymple Trough has been isolated from the Indus infill subsequently to the uplift of the Murray Ridge. On transverse seismic profile (Fig. 4), the core of the Dalrymple Trough is expressed as a syncline. The last deformed layer can be fairly correlated with the Indus sequence at the border of the basin (Fig. 4). It coincides with the reflector marking a major angular unconformity in front of the Makran accretionary wedge (M-unconformity; Gaedicke et al., 2002; Ellouz Zimmermann et al., 2007). Moreover, this reflector marks the base of a fault-controlled contourite drift close to the OFZ at the entrance of the trough (Rodriguez et al., 2014b). Here again, this reflector within well-bedded pelagic layers can be correlated from line to line to the location of the ODP sites. It is also dated at $2.4 \mathrm{Ma}$. However, the age of the northern segment of the Dalrymple Trough, connecting the Ornach Fault in Pakistan, remains to be constrained. 
Detailed tectono-stratigraphic studies indicate the present-day configuration of the entire $800-\mathrm{km}-\mathrm{long}$ OFZ formed at $2.4 \mathrm{Ma}$, expressed by the coeval opening of the Beautemps-Beaupré basin to the south, the $20^{\circ} \mathrm{N}$ basin, and the Dalrymple Trough to the north. Considering the $10-12 \mathrm{~km}$-morphological offsets were formed during the last 2.4 Ma implies a dextral rate of India-Arabia relative motion at $\sim 4.2 \pm 5 \mathrm{~mm} \mathrm{yr}^{-1}$. The IndiaArabia boundary is located in this area since at least the Early Miocene and the first stages of seafloor accretion at the Sheba Ridge ago (Fournier et al., 2010). The India-Arabia plate boundary has accommodated since then about 80-km of dextral relative motion (Chamot-Rooke and Fournier, 2009). When the OFZ formed at $2.4 \mathrm{Ma}$, the India-Arabia boundary was therefore already a mature system. The timing of the formation of the OFZ at 2.4 Ma does not correspond to a clearly identified kinematic change (DeMets et al., 2017), making the geodynamic driver of its formation unknown. Either the corresponding kinematic change has not been detected so far, or there is no kinematic change related to the onset of the OFZ. The formation of the OFZ may simply be the last step of a series of transient adjustments of the India-Arabia plate boundary since the last major kinematic change identified in the Indian Ocean between 6 and $8 \mathrm{Ma}$ (DeMets and Merkouriev, 2016; DeMets et al., 2017). It is also possible that the $2.4 \mathrm{Ma}$ episode of intensification of the Indian Monsoon (An et al., 2001) might have played a role in the evolution of the strike-slip system through its effect on the Indus sedimentation rates (increase up to $500 \mathrm{~m} / \mathrm{Ma}$ at $2.4 \mathrm{Ma}$; Shipboard Scientific Party, 1989).

\section{Acknowledgments}

This study is a synthesis of numerous works based on the multibeam and seismic dataset collected during the AOC, OWEN 1 and 2 surveys in the last decade. All scientists and cruise members (R/V Beautemps-Beaupré, SHOM) involved in these projects are warmly thanked for their help. We thank J. Duarte and T. Minshull for their detailed comments that helped us to improve this synthesis.

\section{Figure captions}

Figure 1 Multibeam bathymetric map of the Owen fracture zone. Inset shows the plate tectonic context in the northwestern Indian Ocean. (a) and (b) are enlargements of two areas where the lateral offset has been measured (respectively 10 and $12 \mathrm{~km}$ ).

Figure 2 (A) Multibeam bathymetric map of the Beautemps-Beaupré Basin $\left(B^{3}\right)[1]$, (B) North-South seismic profile across the Beautemps-Beaupré Basin, and (C) its interpretation (in blue, the post $-2.4 \mathrm{Ma}$ infill of the basin, in black the $8.8 \mathrm{Ma}$ discordance that marks the uplift of the Owen ridge).

Figure 3 (A) Multibeam bathymetric map of the $20^{\circ} \mathrm{N}$ Basin, OFZ: Owen Fracture Zone, SB1, SB2, SB3: subbasins, (B) West-East seismic profile across the sub-basin SB3 of the $20^{\circ} \mathrm{N}$ Basin, and (C) its interpretation (in blue, the post - 2.4 Ma infill of the basin).

Figure 4 (A) Multibeam bathymetric map of the Dalrymple Trough (inset is a bird's eye view from the southwest), (B) West-East seismic profile across the southern part of the Dalrymple Trough, and (C) its interpretation. The pink reflector dated at 2.4 Ma marks the beginning of the opening of the basin. The post -2.4 Ma infill of the basin is shown in blue.

\section{References}

An, Z., Kutzbach, J.E., Prell, W.L., Porter, S.C., 2001. Evolution of Asian monsoons and phased uplift of the HimalayaTibetan plateau since Late Miocene times. Nature 411, 62-66.

Bernard, A., Munschy, M., 2000. Le bassin des Mascareignes et le bassin de Laxmi (océan Indien occidental) se sont-ils formés à l'axe d'un même centre d'expansion ? C. R. Acad. Sci. Paris 330, 777-783.

Bourget, J., Zaragosi, S., Rodriguez, M., Fournier, M., Garland, T., Chamot-Rooke, N., 2013. Late quaternary megaturbidites from the Indus fan: Origin and stratigraphic significance. Mar. Geol. 336, 10-23. https://doi.org/10.1016/j/margeo.2012.11.011.

Brothers, D.S., Driscoll, N.W., Kent, G.M., Harding, A.J., Babcock, J.M., Baskin, R.L., 2009. Tectonic evolution of the Salton Sea inferred from seismic reflection data. Nat. Geosci. 2, 581-584. https://doi.org/10.1038/ngeo590.

Chamot-Rooke, N., Fournier, M., Scientific Team of AOC and OWEN cruises, 2009. Tracking Arabia-India motion from Miocene to Present. American Geophysical Union, Fall Meeting 2009. 
DeMets, C., Merkouriev, S., 2016. High-resolution estimates of Nubia-Somalia plate motion since 20 Ma from reconstructions of the Southwest Indian Ridge, Red Sea and Gulf of Aden. Geophys. J. Int. 207, 317-322. https://doi.org/10.1093/gji/ggw276.

DeMets, C., Gordon, R.G., Argus, D.F., 2010. Geologically current plate motions. Geophys. J. Int. 181, 1-80. https:// doi.org/10.1111/j.1365-246X.2009.04491.x.

DeMets, C., Calais, E., Merkouriev, S., 2017. Reconciling geodetic and geological estimates of recent plate motion across the Southwest Indian Ridge. Geophys. J. Int. 208, 118-133. https://doi.org/10.1093/gji/ggw386.

Dooley, T., Schreurs, G., 2012. Analogue modelling of intraplate strike-slip tectonics: a review and new experimental results. Tectonophysics 574-575, 1-71.

Edwards, R.A., Minshull, T.A., White, R.S., 2000. Extension across the Indian-Arabian plate boundary: the Murray Ridge. Geophys. J. Int. 142, 461-477.

Ellouz Zimmermann, N., et al., 2007. Offshore Frontal Part of the Makran Accretionary Prism (Pakistan) the Chamak Survey. In: Lacombe, O.L. et al., (Ed.), Thrust Belts and Foreland Basins: From Fold Kinematics to Hydrocarbon Systems. Springer, Berlin, pp. 349-364.

Fournier, M., Petit, C., Chamot-Rooke, N., Fabbri, O., Huchon, P., Maillot, B., Lepvrier, C., 2008a. Do ridge-ridge-fault triple junctions exist on Earth? Evidence from the Aden-Owen-Carlsberg junction in theNWIndian Ocean. Basin Res. 20, 575-590. https://doi.org/10.1111/j.1365-2117.2008.00356.x.

Fournier, M., Chamot-Rooke, N., Petit, C., Fabbri, O., Huchon, P., Maillot, B., Lepvrier, C., 2008b. In-situ evidence for dextral active motion at the Arabia-India plate boundary. Nature Geoscience 1, 54-58. https://doi.org/10.1038/ ngeo.2007.24.

Fournier, M., Chamot-Rooke, N., Petit, C., Huchon, P., Al-Kathiri, A., Audin, L., Beslier, M.-O., d’Acremont, E., Fabbri, O., Fleury, J.-M., Khanbari, K., Lepvrier, C., Leroy, S., Maillot, B., Merkouriev, S., 2010. Arabia-Somalia plate kinematics, evolution of the Aden-Owen-Carlsberg triple junction, and opening of the Gulf of Aden. J. Geophys. Res. 115, B04102. https://doi.org/10.1029/2008JB006257.

Fournier, M., Chamot-Rooke, N., Rodriguez, M., Huchon, P., Petit, C., Beslier, M.-O., Zaragosi, S., 2011. Owen fracture zone: the Arabia-India plate boundary unveiled. Earth Planet. Sci. Lett. 302, 247-252. https://doi.org/10.1016/j. eps1.2010.12.027.

Gaedicke, C., Prexl, A., Schl€uter, H.U., Roeser, H., Clift, P., 2002. Seismic stratigraphy and correlation of major regional unconformities in the northern Arabia Sea. In: Clift, P.D., Kroon, D., Gaedicke, C., Craig, J. (Eds.), The tectonic and climatic evolution of the Arabian Sea Region.In: Geol. Soc. (Lond.) Spec. Publ. 195, pp. 25-36.

Le Pichon, X., Sengor, A.M.C., Demirbag, E., Rangin, C., Imren, C., Armijo, R., Gorue, N., Cagatay, N., Mercier de Lepinay, B., Meyer, B., Saatcilar, R., Tok, B., 2001. The active main Marmara fault. Earth Planet. Sci. Lett. 192, 595616.

Le Pichon, X., Imren, C., Rangin, C., Seng€or, A.M.C., Siyako, M., 2013. The South Marmara Fault. Int. J. Earth Sci. 103, 219-231.

Le Pichon, X., Sengor, A.M.C., Kende, J., Imren, C., Henry, P., Grall, C., Karabulut, H., 2016. Propagation of a strike-slip plate boundary within an extensional environment: the westward propagation of the North Anatolian fault. Can. J. Earth Sci. 53, 1416-1439.

Le Pourhiet, L., Huet, B., Traor_e, N., 2014. Links between long-term and short-term rheology of the lithosphere: insights from strike-slip fault modeling. Tectonophysics 631, 146-159. https://doi.org/10.1016/j.tecto.2014.06.034.

Mann, P., 2007. Global catalogue, classification and tectonic origins of restraining- and releasing bends on active and ancient strike-slip fault systems. Geol. Soc. Lond. Special Publ. 290, 13-142.

Massel, G., Coffin, M.F., Mann, P., Mosher, S., Frohlich, C., Duncan, C.S., Karner, G., Ramsay, D., Lebrun, J.-F., 2000. Neotectonics of the Macquarie ridge complex, Australia-Pacific plate boundary. J. Geophys. Res. 105, 13457-13480.

Meckel, T.A., Mann, P., Mosher, S., Coffin, M.F., 2005. Influence of cumulative convergence on lithospheric thrust fault development and topography along the Australian-Pacific plate boundary south of New Zealand. Geochem. Geophys. Geosyst. 6, 20.

Miranda, J.M., Luis, J.F., Lourenc,o, N., Goslin, J., 2014. Distributed deformation close to the Ac, ores triple 'point'. Mar. Geol. 355, 27-35.

Rebesco, M., Hernàndez-Molina, F.J., Van Rooij, D., Wahlin, A., 2014. Contourites and associated sediments controlled by deep-water circulation processes: state of the art and future considerations. Mar. Geol. (352), 111-154.

Rodriguez, M., Fournier, M., Chamot-Rooke, N., Huchon, P., Bourget, J., Sorbier, M., Zaragosi, S., Rabaute, A., 2011. Neotectonics of the Owen fracture zone (NW Indian Ocean): structural evolution of an oceanic strike-slip plate boundary. Geochem. Geophys. Geosyst. 12, Q12006. https://doi.org/10.1029/2011GC003731.

Rodriguez, M., Chamot-Rooke, N., Fournier, M., Huchon, P., Delescluse, M., 2013. Mode of opening of an oceanic pullapart: the $20^{\circ} \mathrm{N}$ Basin along the Owen fracture zone (NW Indian Ocean). Tectonics 32, 1-15. https://doi. org/10.1002/tect.20083.

Rodriguez, M., Chamot-Rooke, N., Huchon, P., Fournier, M., Delescluse, M., 2014a. The Owen Ridge uplift in the Arabian 
Sea: Implications for the sedimentary record of Indian monsoon in Late Miocene. Earth Planetary Science Letters 394, 1-12. https://doi.org/10.1016/j.eps1.2014.03.011.

Rodriguez, M., Chamot-Rooke, N., Huchon, P., Fournier, M., Lallemant, S., Delescluse, M., Zaragosi, S., Mouchot, N., 2014b. Tectonics of the Dalrymple trough and uplift of the Murray ridge (NW Indian Ocean). Tectonophysics 636, 117. https://doi.org/10.1016/j.tecto.2014.08.001.

Rodriguez, M., Huchon, P., Chamot-Rooke, N., Fournier, M., Delescluse, M., 2016. Tracking the Paleogene India- Arabia plate boundary. Mar. Petrol. Geol. 72, 336-358. https://doi.org/10.1016/j.marpetgeo.2016.02.019. Rodriguez, M., Fournier, M., Chamot-Rooke, N., Huchon, P., Delescluse, M., 2018. The geological evolution of the Aden-OwenCarlsberg triple junction (NW Indian Ocean) since the Late Miocene. Tectonics. in press.

Rosas, F.M., Terrinha, P., Duarte, J., Baptista, L., Kullberg, C., Almeida, J., Barata, F., Carvalho, B., Tomàs, R., Almeida, P., 2014. Analog modeling of strike-slip fault (lateral) propagation from an elastic to a viscous medium: insights from trials experiments. Commun. Geol. 101 (especial III), 1429-1432.

Schattner, U., 2010. What triggered the early-to-mid Pleistocene tectonic transition across the entire easternMeditterranean? Earth Planet. Sci. Lett. 289, 539-548. Shipboard Scientific Party (1989), Site 731. In: Prell, W.L., Niitsuma, N., et al. (Eds.), Proc. ODP, Init. Repts., 117. College Station, TX (Ocean Drilling Program). Sylvester, A.G., 1988. Strike-slip faults. Geol. Soc. Am. Bull. 100, 1666-1703.

Tchalenko, J.S., 1970. Similarities between shear zones of different magnitudes. Geol. Soc. Amer. Bull. 81, 1625-1640. ten Brink, U.S., Ben-Avraham, Z., 1989. The anatomy of a pull-apart basin: seismic reflection observations of the Dead Sea. Tectonics 8, 333-350.

ten Brink, U.S., Flores, C.H., 2012. Geometry and subsidence history of the Dead Sea basin: a case forfluid induced midcrustal shear zone? J. Geophys. Res. 117, B01406. https://doi.org/10.1029/2011JB008711.

von Rad, U., Tahir, M., 1997. Late quaternary sedimentation on the outer Indus shelf and slope (Pakistan): evidence from high-resolution seismic data and coring. Mar. Geol. 138, 193-236.

Wakabayashi, J., 2007. Stepovers that migrate with respect to affected deposits: field characteristics and speculation on some details of their evolution. In: Cunningham, W.D., Mann, P. (Eds.), Tectonics of strike-slip restraining and releasing bends. In: 290, Geological Society, London, Special Publications, pp. 169-188.

Wesnousky, S.G., 2005. The San Andreas and Walker Lane fault systems, western North America: transpression, transtension, cumulative slip and the structural evolution of a major transform plate boundary. J. Struct. Geol. 27, $1505-1512$.

Zitellini, N., Gràcia, E., Matias, L., Terrinha, P., Abreu, M.A., DeAlteriis, G., Henriet, J.P., Danobeitia, J.J., Masson, D.G., Mulder, T., Ramella, T., Somoza, L., Diez, S., 2009. The quest for the Africa-Eurasia plate boundary west of the strait of Gibraltar. Earth Planet. Sci. Lett. 282, 13-50. 

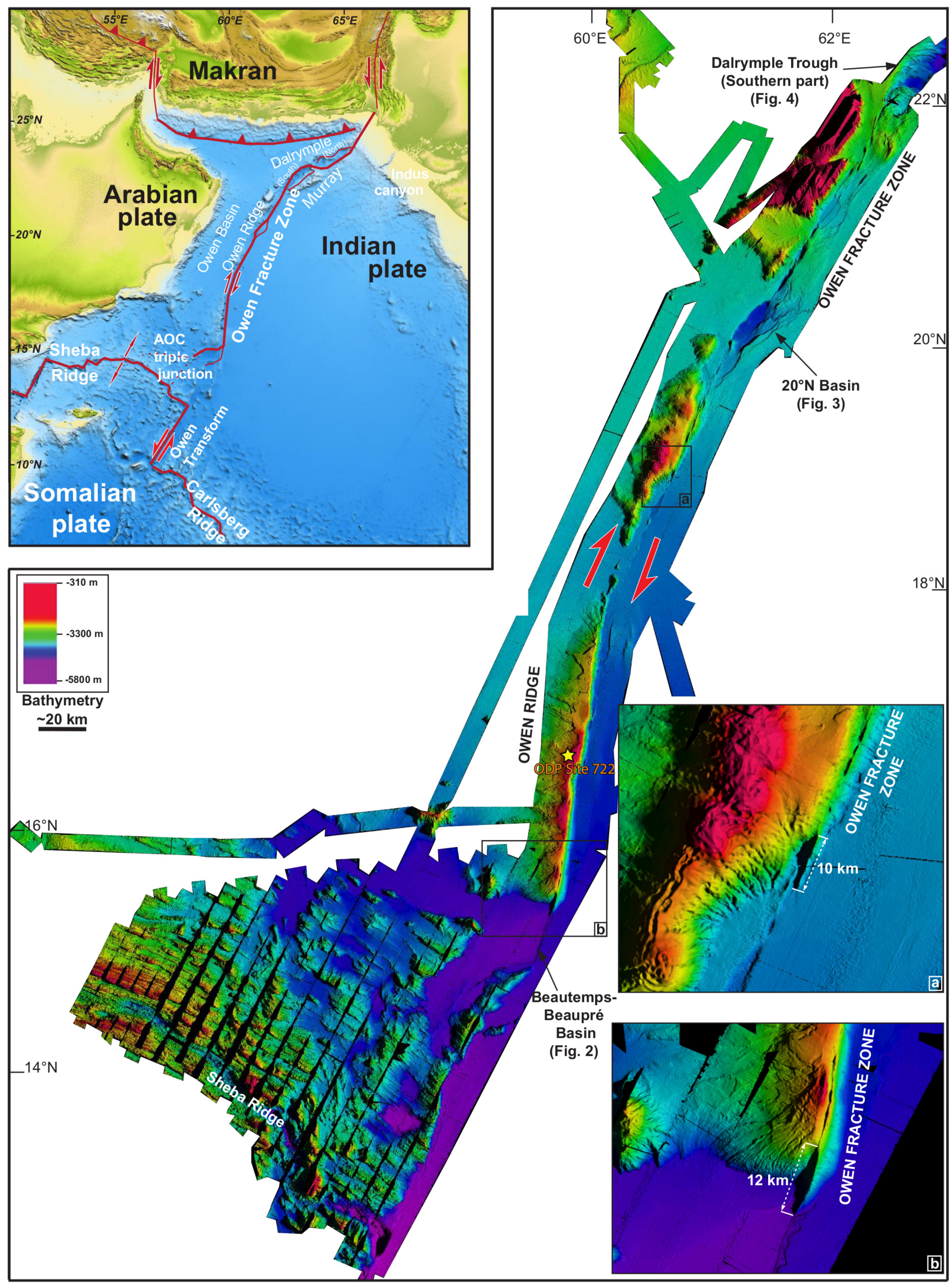

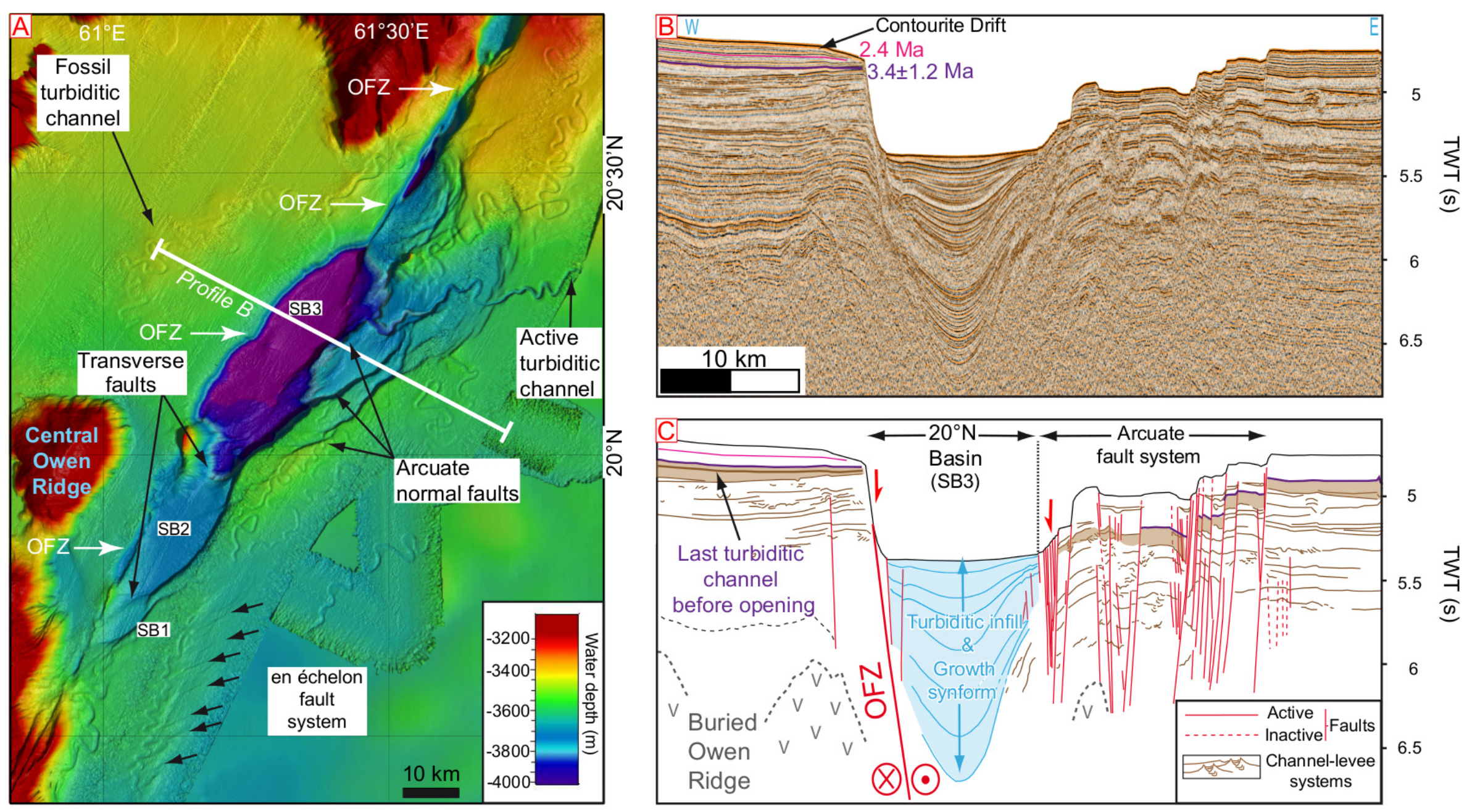

Figure 3 

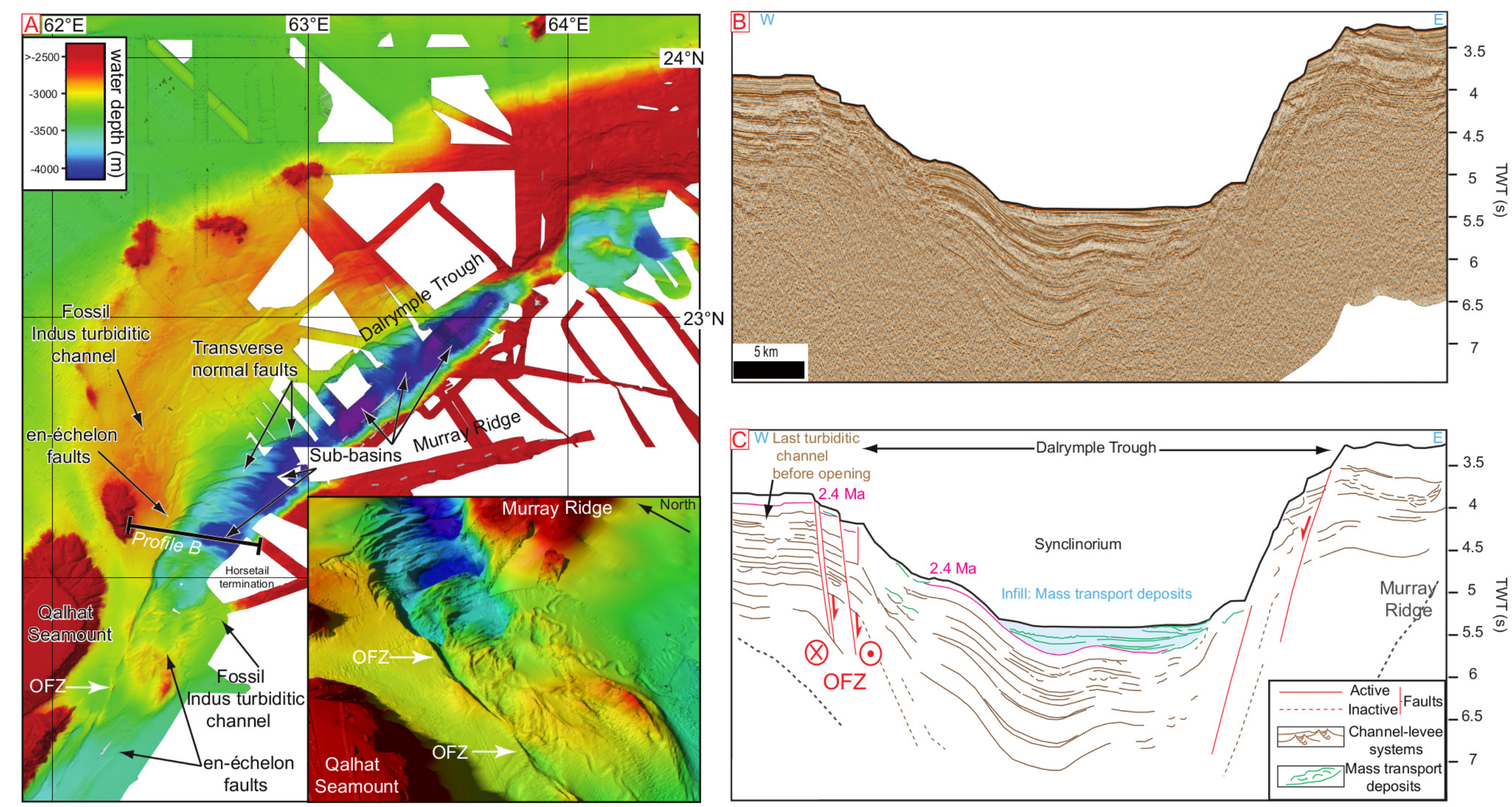